\title{
THE IMPACT OF URBANIZATION PROCESSES ON THE CHANGE OF THE REGULATIONS FOR THE CONSTRUCTION OF THE HISTORICAL QUARTERS OF GAZA (PALESTINE)
}

\author{
Hammouda Nahed Aldohdar, post-graduate student, \\ dohdar.architect@gmail.com, ORCID: 0000-0002-6004-7877 \\ Kharkov National University of Civil and Architecture \\ 40 Sumska Street, Kharkiv, 61002, Ukraine
}

\begin{abstract}
Urbanization processes of the historic urban environment, characteristic of the development of historic cities in the twentieth century, are associated with the redistribution of urban resources, which in most cases have a negative impact on the state and conditions of preservation of the historic environment of old urban centres. The article analyses the impact of urbanization processes on the state of monuments of architectural and archaeological heritage and traditional construction of the old city quarters of Gaza in Palestine. The architectural and archaeological heritage of Palestinian cities is characterized by a diversity of cultures that throughout history have been subject to destruction and transformation caused by the effects of war, changes in political regimes, from Canaanite civilization to the present.
\end{abstract}

Keywords: urbanization processes, population density, archaeological buildings, historic town, Gaza.

Introduction. "Historic heritage are places of significance to people on account of historical, physical (technological, archaeological, architectural) and cultural values. Historic heritage is often referred to as cultural and historic heritage or simply 'historic places"' [1]. The most vulnerable in modern Palestine are the isolated region of the Gaza Strip, which stretches along the east coast of the Mediterranean Sea, and its historic areas, which have preserved the heritage of ancient times and a significant layer of monuments of Islamic architecture. The greatest influence on the degree of preservation and integrity of the historic environment had the period of the twentieth century, during which the historic urban fabric has undergone significant changes: expansion of the main highway, which changed the architectural and planning links of the city centre and its environs, using modern materials instead of environmentally homogeneous natural materials in the construction and improvement of city streets.

Gaza city experienced planning and regulation of its urban development under four different rulers changed the historical character of Gaza City during the last century. These rulers are the British Mandate, Egyptian administration rule, Israeli Occupation and the Palestinian National Authority (PNA). Each ruler left their footprints on the land and contributed to the recent shape and physical spatial structure of Gaza city. It had also substantial impact on the growth pattern and the quality of life for its population. Analysis of the results of the study will help to understand the areas of sustainable development of the historic urban environment.

Analysis of recent research and publications. Preservation and protection of historic city centres - are the focus of research by many scientists. The material of the article is based on the following scientific works: Al-Farra M. K. "Proposed solutions for future urban growth in Gaza Strip", Al-Qeeq F. "A comprehensive approach to incorporate architectural heritage of Gaza old", El-Saqqa N. \& Mohamed A. A. "Urban Space in Historic City Centers: The Search for Genius-Loci in Palestine Square, Gaza City", Abuelaish B. \& Olmedo M. T. "Scenario of land use and land cover change in the Gaza Strip using remote sensing and GIS models", Almughany N., El-Wazir M., Al-Qeeq F. \& Dawood H. "A sustainable approach for the urban integration of HAMMĀM SAMĀRAH in historic City of Gaza". 
Formulation of the problem. One of the main, the research focuses on identifying and arranging the problems facing the Gaza Strip, the factors which cause the changes, the potential adverse effects of new interventions due to urbanization, Careless of the potential adverse effects of new interventions due to urbanization, these factors threaten the existing urban fabric of Old city.

Drawn by this aim, the following question should be answered: What is the effect of the political, economic, social, cultural and religious influences on the Old city? So it should find new strategies that is able to fulfil a distinguished character for the city as well as sitting aside the relation between the city's character on one hand and the political, economic and social influences on the other and proper measures to balance the urbanization and the historical heritage settings should be undertaken. As well as identifying and arranging the most important solutions necessary for the development of the Gaza Strip and assembled and clarified to confirm their importance.

The purpose of the study: to identify the dynamics of population growth and the nature of changes in the state of monuments, traditional urban development, environment and culture. The research model presents the mechanisms of identification of cultural heritage sites, depending on the factors influencing the state of the historical environment: social, economic, ecological, architectural and spatial.

The nature of the impact of urbanization is determined by the values of heritage assessment: the degree of physical preservation of heritage sites in the historic quarter, architectural details and integrity of the compositional solution of the building front, building height and degree of silhouette, the number of new inclusions that preserve the historical context. height of buildings, number of places, value of land, type of ownership and others that should be classified according to the objectives of the study.

The main material. Gaza Strip is located in the south-western part of Palestine; it extends on the Mediterranean coast with a length of about $45 \mathrm{~km}$ and a width that ranges between 6-12 km, with an area of about $360 \mathrm{sq}$. km [2]. Gaza's history of habitation dates back 5.000 years, making it one of the oldest cities in the world. Located on the Mediterranean coastal route between North Africa and the Levant, for most of its history it served as a key warehouse of southern Palestine and an important stopover on the spice trade route traversing the Red Sea [3]. In spite of the ancient traditions of urban development in Palestine, the development of the Palestinian cities has veered from these traditions and suffered greatly since the middle of the twentieth century and has been dominated by many peoples and empires throughout its history. It was incorporated into the Ottoman Empire in the early 16th Century. Following World War II, Gaza became part of the British Mandate in Palestine. The various political systems under the former ruler of the Palestine land had influenced the urban planning policies.

Since the beginning of the second half of the nineteenth century [4], the Ottoman had ruled the Palestine land until the British took control of the land in 1917. From 1948-1967, the Jordanian Kingdome had controlled areas in the West bank, and the Egyptian had also conquered areas along the Gaza Strip. In 1967, Israel occupied the West Bank and the Gaza Strip, in addition to Golan Heights and Sinai Peninsula [5].

The British Mandatory Period (1917-1948): the term "urban planning" first appeared in 1906, with the establishment of urban planning system in Britain in 1909. It was a result of the environmental and social problems caused by the industrial revolution. The British town planning was implemented in all British controlled colonies such as India, Nigeria, Malaysia and Palestine [6].

The Egyptian administration Period (1948-1967): the Egyptian government adopted a law for the Gaza Strip in order to change the Palestinian laws before 1948. In that period, expanded the streets, and removed many antique buildings. The urban settlement experienced building sprawl and changes in the general layout and size of these settlements in accordance with the expansion of the municipal boundaries under Egyptian policies.

The Israeli occupation Period (1967-1994): this affected the urban planning and urban form of Palestinian settlements, the Israeli authorities issued much military regulation to control and reduce urban growth and expansion in the Palestinian habitation. The procedures for building permits request for all construction were very complex [6].

The Palestinian National Authority Period: the planning responsibilities as well as other civilian issues and services were transferred to the related Palestinian ministries and institutions. When the

Bulletin of Odessa State Academy of Civil Engineering and Architecture, 2020, no. 80, page 9-18 
Palestinian National Authority (PNA) started self-rule in the West Bank and Gaza, it faced with the multiplied task of planning for its future needs and at the same time having to accommodate the planning needs generated by donor projects. For the Palestinians, neither the existing regional planning schemes nor their attributed regulatory framework within the occupied territories constituted an appropriate and relevant approach for meeting the overall political, socio-economic and physical needs of the population generated through the contemporary developments [5].

Gaza city: urbanization and architecture heritage changes: Gaza had maintained the unique style and individual flavour of its urban fabric. Over the past few decades, however, Gaza has been beset by a growing pressure of urbanization whose thirst for development has little concern for the historical attributes of the built heritage. Particularly, in the historic centre of town.

Study area: Old town, a historical town in Gaza city in Palestine was chosen for our study area (Fig. 1, Fig. 2). The Old town forms the main part of Gaza's nucleus.

a)

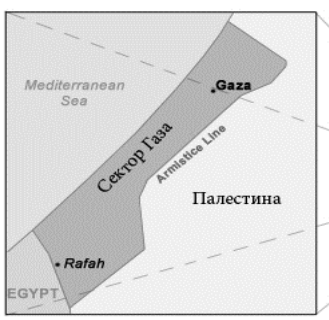

b)

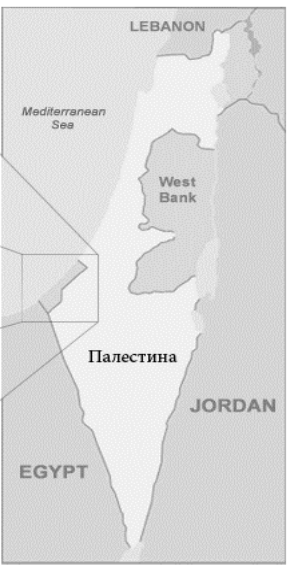

Fig. 1. Gaza City as a study area:

$a$ - Palestine map showing the location of Gaza [7]; $b$ - old town map of Gaza city showing municipal boundaries $[8]$

It is roughly divided into two quarters; the northern Daraj Quarter (also known as the Muslim Quarter) and the southern Zaytun Quarter (which contained the Christian quarters). Most structures date from the Mamluk and Ottoman eras [4], and some were built on top of earlier structures. The ancient part of the Old City is about 1.6 square kilometres (0.62 sq. mi). The selected study area has important heritage features at risk of disruption by urbanization processes and commercial development.

a)

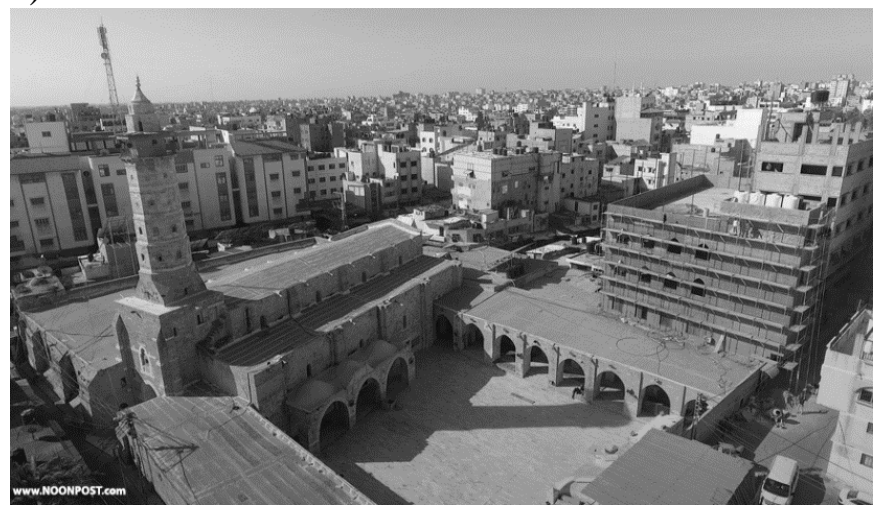

b)

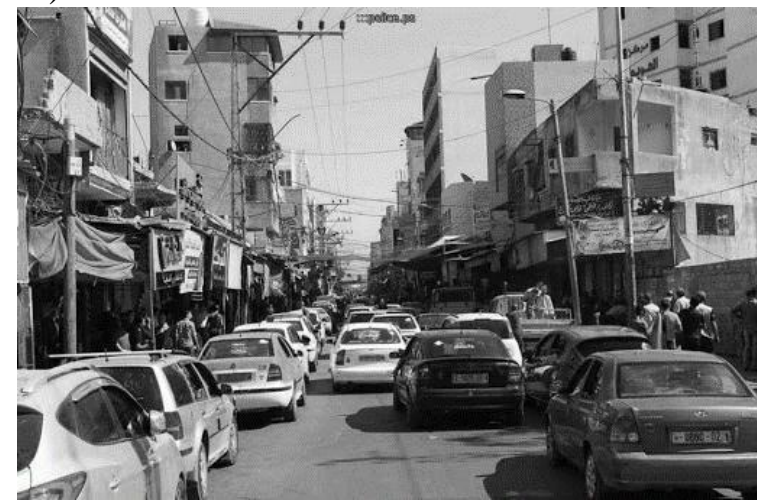

Fig. 2. Old City of Gaza City:

a - Al-Omari Grand Mosque - the most important and oldest archaeological buildings in the old town centre [9]; $\mathrm{b}$ - visual distortion and changes to the old town buildings [10] 
Variable selection: Variables delineating physical, socioeconomic and sociocultural factors of the buildings. The driving factors for changes in the buildings were the predictor variables as follows: Architectural Elements, Building Construction Materials, Building Height, Number of Occupancies, Land Value, Ownership Type, Real World Factors, and Building Use. The commercial buildings are more likely to undergo a high level of change than buildings used for other purposes and that building use has a significant positive impact on the built heritage. Analysis of the effects of urbanization processes on the architecture heritage in old town of Gaza city, Fig. 3.

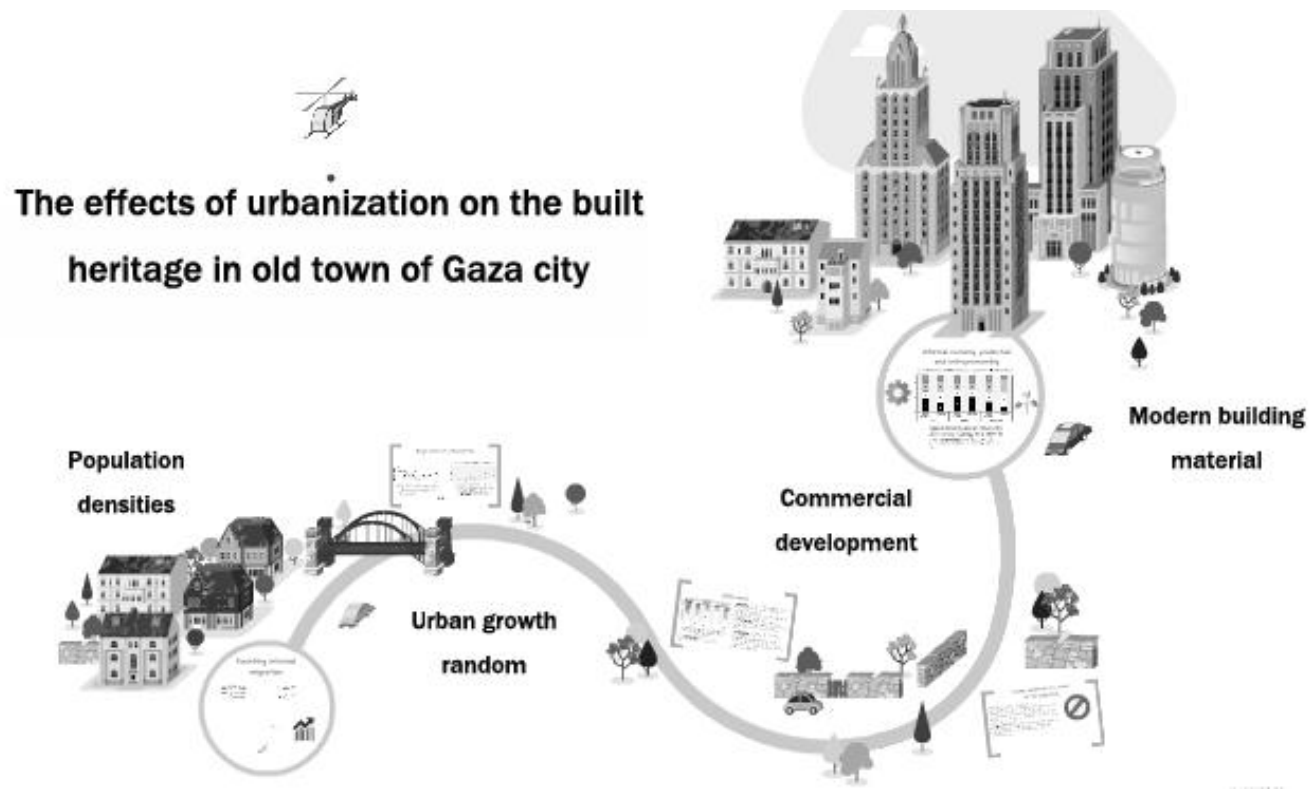

Fig. 3. The effects of urbanization processes on the architecture heritage in old town of Gaza city

[Design Researcher]

1. Population densities: The population of the Gaza Strip for the year 2019 is estimated at 1.99 million [11]. Gaza has one of the highest population densities in the world, making it the largest city in the State of Palestine. Inhabited since at least the 15th century BCE [12]. On average, some 5.479 people live on every square kilometre in Gaza, Fig. 4. The number of people living there is expected to hit 3.1 million by 2030 [13].

a)

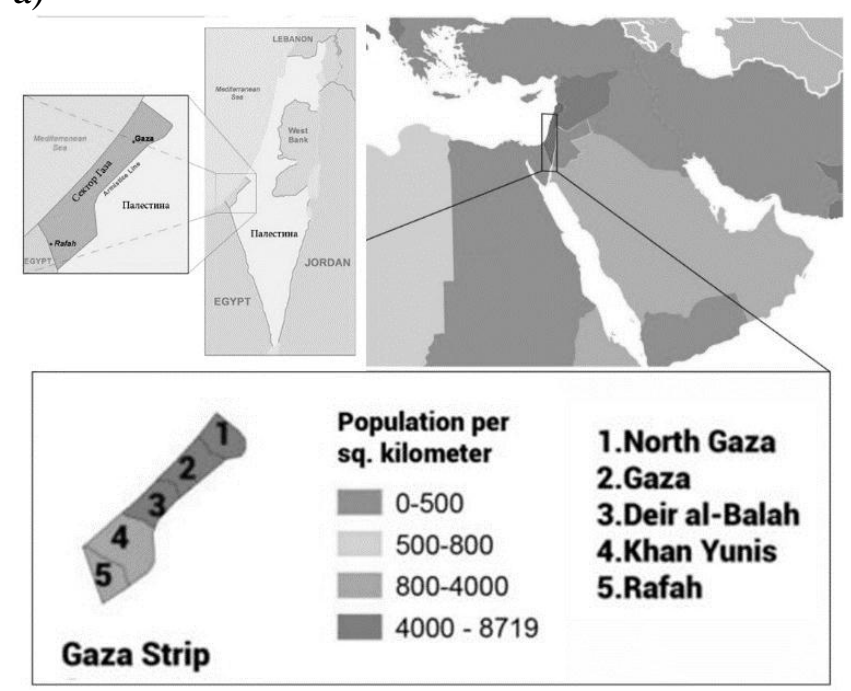

b)

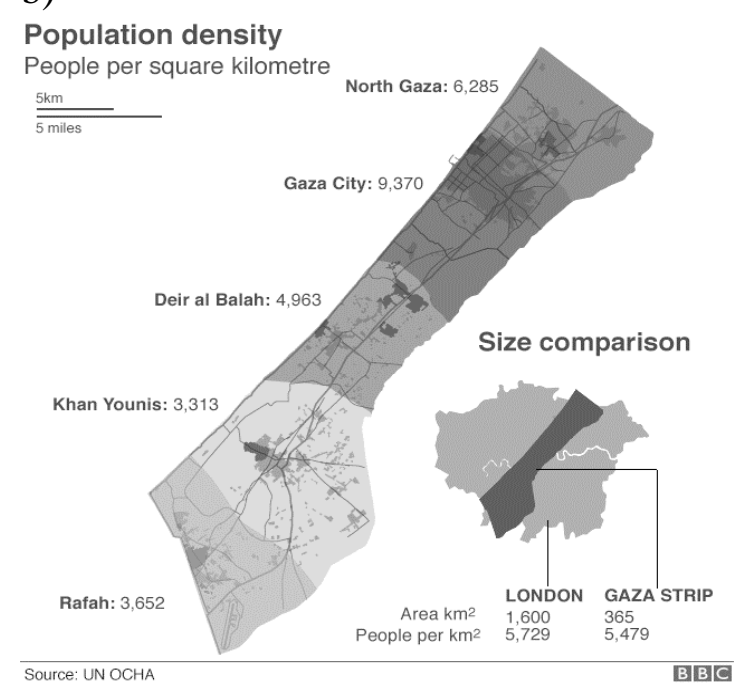

Fig. 4. Population density in the Gaza Strip:

$\mathrm{a}$ - distribution of population among the governorates of the Gaza Strip per sq. kilometer [14]; $\mathrm{b}$ - comparing the population density between the Gaza Strip and London [13] 
1.1. Gaza Population History: The earliest record of Gaza's population shows 6.000 people living in the city in 1596, which made it the third largest city of Ottoman Palestine at the time after Jerusalem and Safad, Fig. 5. Gaza's 2020 population is now estimated at 713.621 [15].

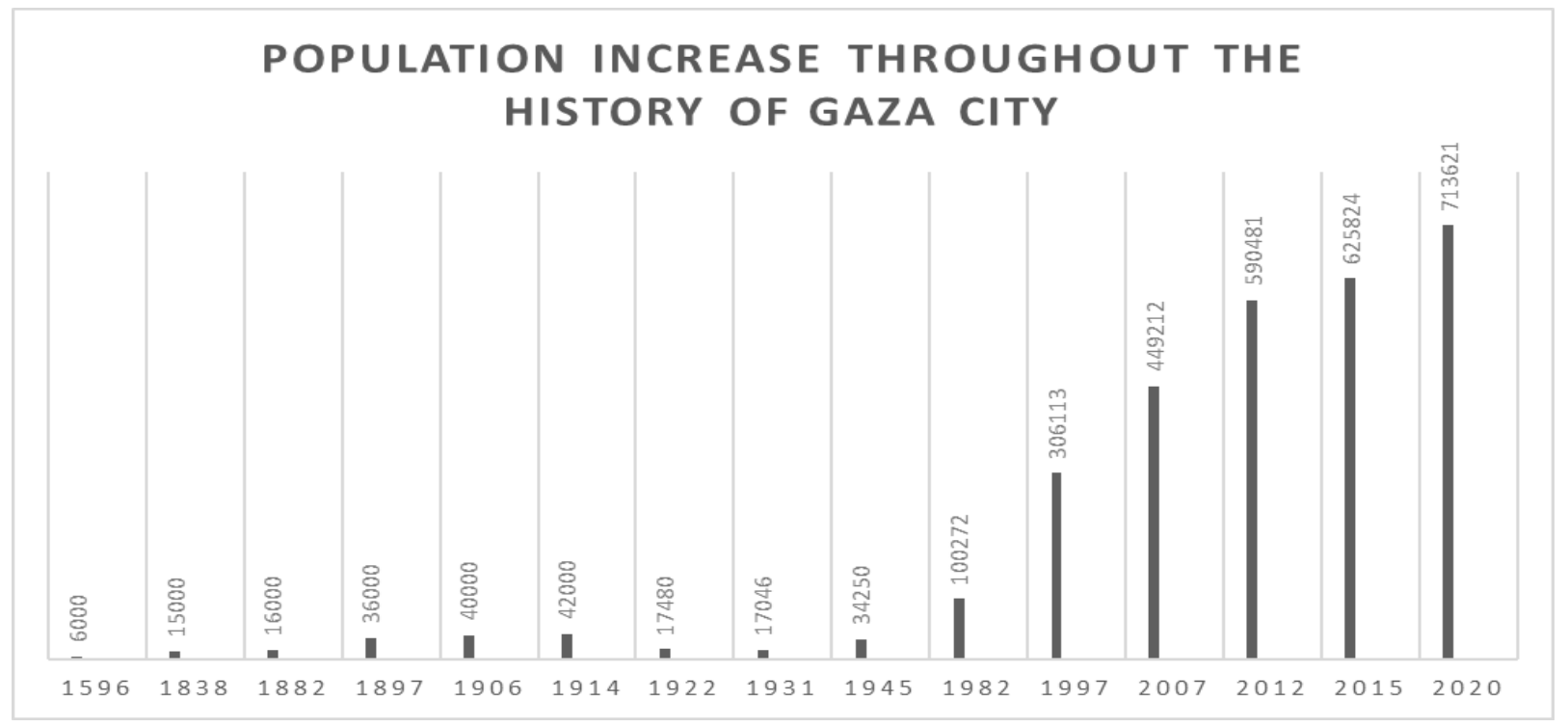

Fig. 5. Graph showing the Demographics Population of Gaza city of the study area [4]

The city is already very crowded with limited space for new construction. An increasing urban population with different needs and aspirations and uncontrolled development are drastically transforming the character of historic areas. This transition can destroy the individuality of the historic urban fabric, making all towns seem similar.

2. Urban growth random: Development of towns and cities is not certainly destructive, but haphazard growth, the ungovernable intrusion of modernization, poor planning and inadequate awareness of heritage values combine to produce a host of problems that threaten the tangible and intangible heritage. UNESCO's recommendations on planning for the Historic Urban Landscape emphasize that the urban heritage is a social, cultural, and economic asset [16]. During the twentieth century, the influx of modernism and large-scale reconstruction spurred many cities to elicit change by the rejection of traditional architecture, building techniques, and materials in favour of more modern methods [1].

3. Commercial development: Historic towns often exhibit a rich mixture of social, cultural, architectural and historical heritage values $[17,18]$. However, streetscapes, urban fabrics and buildings are developing and changing to suit the demands of stakeholders while the role of urbanization in preserving the heritage characteristics of the environment is ignored. It is the responsibility of stakeholders to work for conserving the distinctive character and quality of the historic environment for future generations. Commercial establishment speeds overcome the residential settings which induce to change the building use. In this process, the buildings keep modified and intervening in global trends results in the loss of the built heritage settings. The town was familiar for a key warehouse of southern Palestine and an important stopover on the spice trade route traversing the Red Sea [19], passed on from generations to generations. Fig. 6 shows the spice shop in Alzawiah market in the middle of the old town. Only a few shops exist in the traditional style, and others are modified to the current trend, Fig. 7.

Further, the land values have increased in the recent decades. The building owners kept partitioning their buildings and rented them for commercial purposes. The streetscapes and skylines are mostly affected by these changes.

4. Modern building material: Sandstone material was used over very long periods of time in Gaza. It was considered the basic building material for permanent buildings and houses of rich people, who could afford it. It used to be mined from ancient quarries located to the east and north directions of the old city of Gaza. Currently, the quarries are almost no longer available, as they were covered by the 
expansion of the city built up areas, especially after the stop of using such material in buildings in the middle of the last century. In Gaza City there are many traditional houses built of sandstone which still preserve their distinctive architectural design and elements [20]. With the entry of cement material to Gaza in the first half of the 20th century, concrete houses, made mainly of concrete material, spread and became the most common way of construction (Fig. 2). Concrete allowed the construction of multi-storey buildings, Fig. 5. However, this seems to have resulted in a relatively new architectural style that lacks relation to local architectural features and traditions of the community [20].

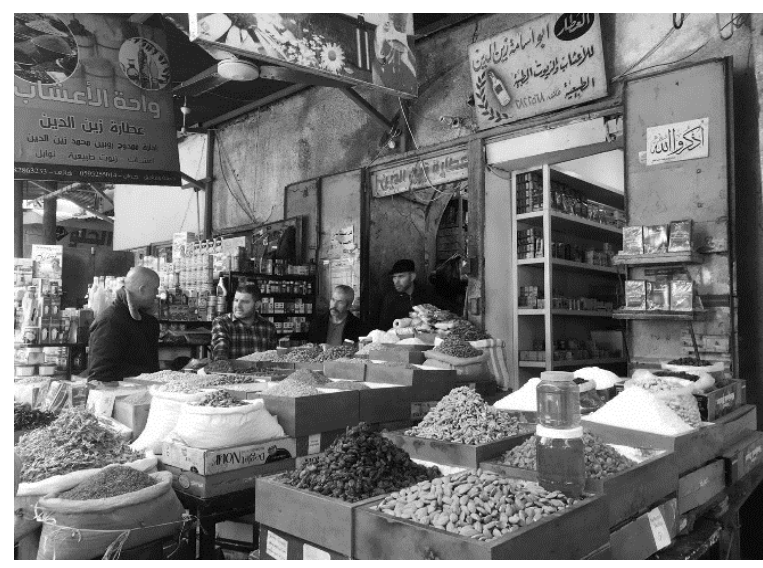

Fig. 6. The spice shop in Alzawiah market in the middle of the old town [11]

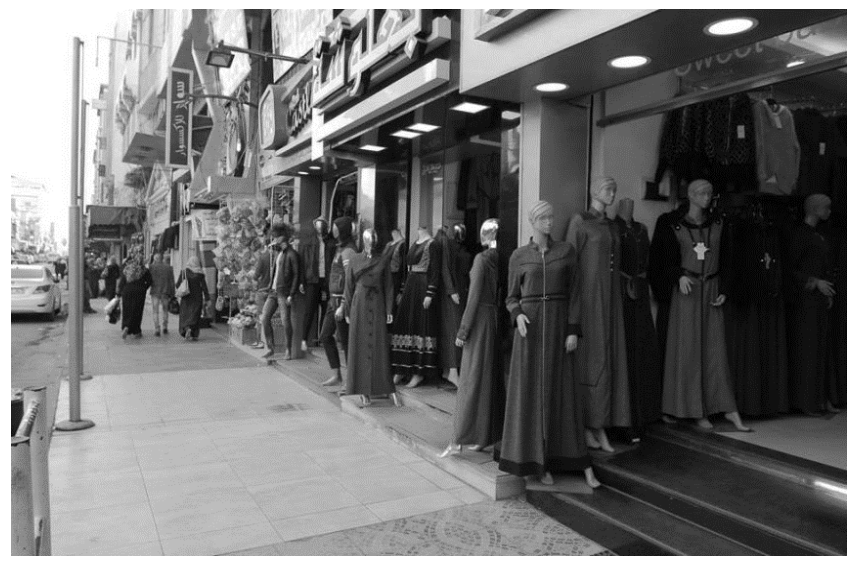

Fig. 7. Commercial buildings with contemporary architecture (Omar Al-Mukhtar Street) [10]

Architectural change of buildings: The architectural design of house buildings in the Gaza strip has changed dramatically during the last few decades, moving from the traditional courtyard type to the temporary style of concrete houses. Fig. 8, which spread in most Arab and world countries [21].

a)

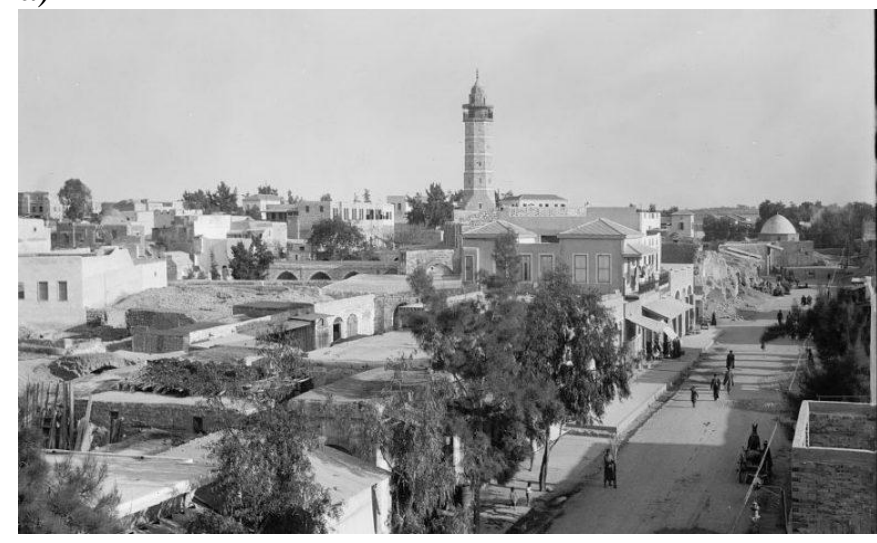

b)

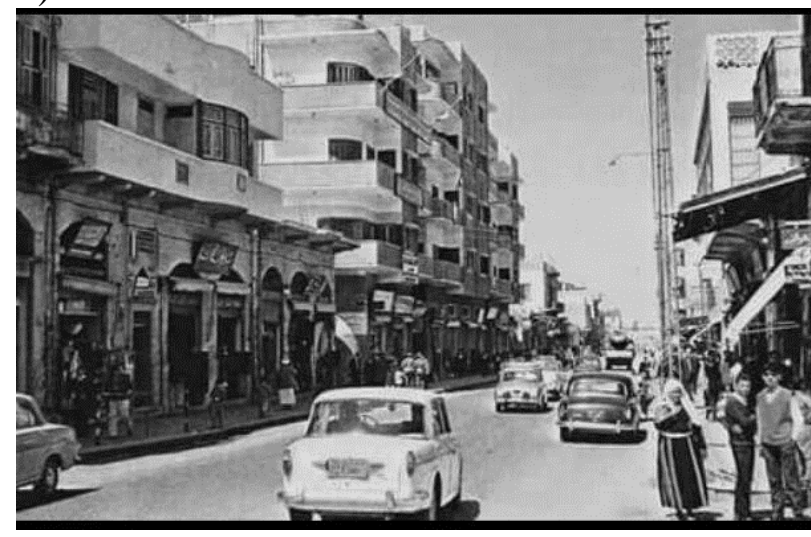

Fig. 8. Omar Al-Mukhtar Street, beginning and mid-twentieth century, and its extent affected by urbanization:

a - Gaza main street, approximately 1920 to 1933 [22]; b - Gaza main street 1960 [23]

Factors that affect the urban development and urban planning can be summarized as follows:

The multiplicity of governments and relevant laws with urban planning - has led to the disappearance of the urban and historical character of the city.

1. Frequent wars and the siege imposed on the Gaza Strip - led to the random planning of the city.

2. Political differences - led to the absence of building and planning laws.

3. Limited space - led to increased population density.

4. Modern technology - led to the rapid growth of urbanization and the absence of a heritage character. 
Historically, urban planning in Palestine is influenced by different political rules. The ruling power is behind the formation of local authorities with existing inter-mix community. These authorities failed under the central authority's framework of political and directorial dependency which limited their ability to provide quality public services [5].

The most important urbanization processes of the historical territory of Gaza City can be summarized as follows: Multi-storey vertical buildings to respond to the growing need for housing, in a very limited area of land; design of large external openings without affecting the construction system; increase of the population density as a result of vertical building design; the disappearance of green spaces in the centre of the old town; the disappearance of the historical styles of the old town buildings and losing many of the traditional architectural elements in buildings, which are considered the most important symbols of the local architecture in Gaza, such as the courtyard, arches, domes, ornaments, Iwan and others.

Conclusions. Urban planning in Palestine is a result of the historical precedents and the unstable political and economic situation on the cities. In this study, identified and investigated the factors correlated with urbanization-related changes in building in the selected study area of Gaza town. The main challenges are the following: Population densities; urban growth random; Commercial development; unstable political situation and Modern building material. It is evident that the Population density had a significant impact on the Urbanization led to changes in the built heritage which are gradually decaying the heritage character of the city and also the political situation in the country played a major role in relapsing the landscapes, cultural and historical sites, and natural resources and environment. The results are clearly explaining that the buildings with the high level of changes occurred in the study area of Gaza which were induced by political and economic variables. Notably, changes in the building materials, architectural elements, building height, building use are considered the primary factors which influenced the buildings heritage character. By controlling these factors, we can able to revive the town's heritage characters which need proper local development plan. Without regulations and directives, the urban planners follow their ideas which seldom involved heritage preservation. Even when the ancient buildings are spared, they are so modified by replacement of traditional materials and styles with the current crop of contemporary architectural styles that they become painful to view.

1. It is vital to focus on the built heritage and its characteristic influences on the sociocultural life of the town in order to preserve as much of its heritage as possible.

2. The identified factors were highly associated with changes in the physical, socioeconomic, and sociocultural aspects of the town's buildings within which the built heritage and its unique characteristics exist.

3. In the case of physical factors, such as the architectural elements, building materials, and building height, the municipal administration and local development plan guidelines need to accord more consideration for the built heritage and its urban fabric.

4. Commercial pressures as highlighted in the building use factor, emphasize how important this aspect of urban planning is to halt the decline in a town's traditional heritage characters.

5. Socioeconomic factors like the number of occupants, changes in land value and ownership type are also of critical importance in developing strategies for allowing new developments and interventions without compromising historical integrity.

In the context of historic towns like Gaza, clear and positive guidelines need to be established for the conservation of the built heritage to retain and revive the character of the town. While urbanization and development of a town are inevitable, it is not incompatible with growth in the conservation of the uniquely valuable characteristics of the architectural heritage and creates a town people can call home. The planning authorities, local architects, stakeholders and the population of the town, all together, should develop appropriate measures to maintain of their historical heritage. 


\section{References}

[1] S. Macdonald, "Contemporary Architecture in Historic Urban environments". The Getty Conservation Institute. Conservation perspectives, Los Angeles, [Online]. Available: https://www.getty.edu/conservation/publications_resources/newsletters/26_2/contemporar y.html.

[2] Khalid F. Ubeid and Alhasan S. Albatta, "Sand Dunes of the Gaza Strip (Southwestern Palestine): Morphology, Textural Characteristics and Associated Environmental Impacts", Earth Sciences Research Journal, 18, no. 2, pp.131-142, 2014.

[3] Alan Johnston, "Gaza's ancient history uncovered", BBC news. [Online]. Available: http://news.bbc.co.uk/2/hi/middle_east/4365440.stm.

[4] The reader view of WIKIPEDIA, "Gaza City", article is about the city. For the territory. [Online]. Available: https://thereaderwiki.com/en/Gaza_city\#cite_ref-Dumper_12-1.2020

[5] R. Khamaisi, "Israeli Use of the British Mandate Planning Legacy as a Tool for the Control of Palestinians in the West Bank", Planning Perspectives, 12, pp. 321-340, 1997.

[6] A. Abdelhamid, "Urban development and planning in the occupied Palestinian territories: impacts on urban form", Conference on Nordic and International Urban Morphology: Distinctive and Common Themes, pp. 1-17, 2006.

[7] H. Aldohdar, K.T. Cherkasova, "Approaches to preserving the cultural heritage of archaeological buildings from the risks of repeated wars in the city of Gaza - Palestine (Example: reconstruction and restoration of the Al-Kozomri Mosque)", International Journal of Scientific and Engineering Research, Copenhagen N.V., Denmark, vol. 8, Issue 89, pp. 91-97, 2019.

[8] N. El Namara, "A Proposed Approach for the Rehabilitation of Historical Buildings Possessing a Special Value in Gaza City Hammam Alsamra as a Case Study", AlQadisiyah Journal of Engineering Sciences, vol. 7, Issue 4, pp. 134-160, 2014.

[9] Amjad Arafat, "Al-Omari Mosque, Gaza ... A witness and maker of history and religions through the ages", Non Post. [Online]. Available: https://www.noonpost.com/content/27917.

[10] Khaled Al-Swairki, "The municipality police in Gaza Governorate removes the Infringements from Omar Al-Mukhtar Street", [Online]. Available: http://www.police.ps/ar/include/plugins/news/news.php?action=s\&id=12150.

[11] PCBS: Palestinian Central Bureau of Statistics, "On the occasion of the International Population Day 11/7/2019", State of Palestine. [Online]. Available: http://www.pcbs.gov.ps/post.aspx?lang=en\&ItemID=3503\#.

[12] Fitzroy Dearborn, "Gaza (Gaza Strip)", International Dictionary of Historic Places, pp. 87-290, 1996.

[13] UN (OCHA), "Israel-Palestinian conflict: Life in the Gaza Strip", BBC News Services. [Online]. Available: https://www.bbc.com/news/world-middle-east-20415675.

[14] M. Abed, "Population of Palestine", CFANACK. [Online]. Available: https://fanack.com/palestine/population/.

[15] World Population Review 2020, "Gaza Population 2020". [Online]. Available: shane@worldpopulationreview.com.

[16] UNESCO, "Recommendation on the Historic Urban Landscape, including a glossary of definitions", 2011.

[17] N. Cohen, "Urban Conservation". MIT Press, Cambridge, Mass. 1999.

[18] G. Cullen, "The Concise Townscape". Van Nostrand Reinhold, New York. 1961.

[19] Ibrahim M. Al-Resini, "The Water Resources structures on the Syrian and Egyptian pilgrim routes to Makkah and Al-Madinah", PhD thesis. School of Geography. University of Leeds. 1992.

[20] Ahmed S. Muhaisen, "Development of the House Architectural Design in the Gaza Strip", Athens Journal of Architecture, vol. 2, Issue 2, pp. 131-150, 2016. 
[21] Eman Ismail, "Evaluation and Development Study of Housing Types Used in the Gaza Strip to Rebuild the Place Identity", The 4th International Engineering ConferenceTowards Engineering of 21st Century, Palestine: Islamic University of Gaza, pp.1-13, 2012.

[22] American Colony (Jerusalem). Photo Department, "Gaza Main Street, approximately 1920 to 1933", Library of Congress, [Online]. Available: https://www.loc.gov/pictures/item/2019712823/.

[23] Nasser Al-Sowair, "How was the Gaza Strip formed?" Ramallah - Dunia Al-Watan, [Online]. Available: http://bit.ly/2tzO9RS.

\title{
ВПЛИВ ПРОЦЕСІВ УРБАНІЗАЦІЇ НА ЗМІНУ РЕГЛАМЕНТУ ЗАБУДОВИ ІСТОРИЧНИХ КВАРТАЛІВ М. ГАЗИ (ПАЛЕСТИНА)
}

\author{
Алдохдар Х., аспірант, \\ dohdar.architect@gmail.com, ORCID: 0000-0002-6004-7877 \\ Харківський національний університет будівництва та архітектури \\ вул. Сумська, 40, Харків, 61002, Україна
}

\begin{abstract}
Анотація. Процеси урбанізації історичного міського середовища, характерні для розвитку історичних міст в XX столітті, пов'язані 3 перерозподілом ресурсів міської забудови, які в більшості випадків, чинять негативний вплив на стан і умови збереження історичного середовища старих міських центрів. У статті проаналізовано вплив процесів урбанізації на стан пам'яток архітектурно-археологічної спадщини та традиційної забудови старих міських кварталів м. Гази в Палестині. Архітектурно-археологічна спадщина палестинських міст характеризується різноманітністю культур, які впродовж всієї історії існування були схильні до руйнувань і трансформацій, викликаних наслідками воєн, змінами політичних режимів, починаючи від ханаанської цивілізації до теперішнього часу. Найбільш вразливим на території сучасної Палестини є відокремлений регіон сектора Гази, що простягнувся вздовж східного узбережжя Середземного моря, і його історичні райони, які зберегли спадщину давніх епох і значний пласт пам'яток ісламської архітектури.

Найбільший вплив на ступінь збереження і цілісність історичного середовища надав період XX століття, протягом якого в історичній міській тканині намітилися значні перетворення: розширення головної транспортної магістралі, яка змінила архітектурнопланувальні зв'язки міського центру та околиць, включення сучасної індустріальної забудови в історичну тканину міського центру, використання сучасних матеріалів замість екологічнооднорідних природних матеріалів в будівництві та благоустрої міських вулиць. Мета дослідження: виявлення динаміки зростання населення та характеру змін стану пам'яток, традиційної міської забудови, середовища і культури. У моделі дослідження представлені механізми ідентифікації об'єктів культурної спадщини, в залежності від факторів впливу на стан історичного середовища: соціальних, економічних, екологічних, архітектурно-просторових. Характер впливу процесів урбанізації визначається значеннями показників оцінки спадщини: ступеня фізичного збереження об'єктів спадщини на ділянках історичного кварталу, архітектурні деталі і цілісність композиційного рішення фронту забудови, висотність забудови і ступінь збереження силуету, число нових включень, що зберігають історичний контекст, будівельні матеріали, висота будівель, кількість місць, вартість землі, тип власності та інші, які повинні бути класифіковані відповідно до завдань дослідження. Аналіз результатів дослідження буде сприяти розумінню напрямків збереження сталого розвитку історичної міського середовища.
\end{abstract}

Ключові слова: процеси урбанізації, густота населення, археологічні споруди, історичне містечко, Газа. 


\title{
ВЛИЯНИЕ ПРОЦЕССА УРБАНИЗАЦИИ НА ИЗМЕНЕНИЕ РЕГЛАМЕНТА ЗАСТРОЙКИ ИСТОРИЧЕСКИХ КВАРТАЛОВ Г. ГАЗЫ (ПАЛЕСТИНА)
}

\author{
Алдохдар X., аспирант, \\ dohdar.architect@gmail.com, ORCID: 0000-0002-6004-7877 \\ Харьковский национальный университет строительства и архитектуры \\ ул. Сумская, 40, Харьков, 61002, Украина
}

\begin{abstract}
Аннотация. Процессы урбанизации исторической городской среды, характерные для развития исторических городов в XX веке, связанные с перераспределением ресурсов городской застройки, которые в большинстве случаев, оказывают негативное влияние на состояние и условия сохранения исторической среды старых городских центров. В статье проанализировано влияние процессов урбанизации на состояние памятников архитектурно-археологического наследия и традиционной застройки старых городских кварталов м. Газы в Палестине. Архитектурно-археологическое наследие палестинских городов характеризуется разнообразием культур, которые на протяжении всей истории существования были подвержены разрушениям и трансформаций, вызванных последствиями войн, изменениями политических режимов, начиная от ханаанской цивилизации до настоящего времени. Наиболее уязвимым на территории современной Палестины является отделенный регион сектора Газы, протянувшийся вдоль восточного побережья Средиземного моря, и его исторические районы, которые сохранили наследие древних эпох и значительный пласт памятников исламской архитектуры.

Наибольшее влияние на степень сохранности и целостности исторической среды предоставил период XX века, в течение которого в исторической городской ткани наметились значительные преобразования: расширение главной транспортной магистрали, которая изменила архитектурно-планировочные связи городского центра и окраин, включение современной индустриальной застройки в историческую ткань городского центра, использование современных материалов вместо экологически однородных природных материалов в строительстве и благоустройстве городских улиц. Цель исследования: выявление динамики роста населения и характера изменений состояния памятников, традиционной городской застройки, среды и культуры. В модели исследования представлены механизмы идентификации объектов культурного наследия, в зависимости от факторов влияния на состояние исторической среды: социальных, экономических, экологических, архитектурно-пространственных. Характер влияния процессов урбанизации определяется значениями показателей оценки наследия: степень физической сохранности объектов наследия на участках исторического квартала, архитектурные детали и целостность композиционного решения фронта застройки, высотность застройки и степень сохранности силуэта, число новых включений, сохраняющие исторический контекст, строительные материалы, высота зданий, количество мест, стоимость земли, тип собственности и другие, которые должны быть классифицированы в соответствии с задачами исследования. Анализ результатов исследования будет способствовать пониманию направлений сохранения устойчивого развития исторической городской среды.
\end{abstract}

Ключевые слова: процессы урбанизации, плотность населения, археологические сооружения, исторический городок, Газа.

Стаття надійшла до редакції 18.05.2020 